\title{
INCIDENCE AND SEVERITY OF COFFEE LEAF RUST, CERCOSPORIOSIS AND COFFEE LEAF MINER IN COFFEE PROGENIES
}

\author{
Amador Eduardo de Lima ${ }^{1}$, Hudinilson Gilberto Sampaio Junior², Elisa de Melo Castro ${ }^{3}$, \\ Samuel Pereira de Carvalho ${ }^{4}$, Fabiano França da Silva ${ }^{5}$, Sebastião de Lima Junior ${ }^{6}$, \\ Alex Mendonça de Carvalho ${ }^{7}$
}

(Received: May 08, 2018; accepted: July 31, 2018)

\begin{abstract}
Coffee leaf rust is the main disease of this crop, however cercosporiosis and coffee leaf miner can also cause significant damage when they reach high levels of infestation. Plant genetic improvement for resistance is one of the best tools for controlling plant diseases. The objective in this work was to identify $\mathrm{F}_{3}$ progenies of Coffea arabica with resistance to coffee leaf rust, which present a lower incidence and severity of cercosporiosis and coffee leaf miner. The treatments were constituted by 10 progenies, besides two cultivars coffee leaf rust susceptible, used as a control. The experimental design was a randomized block design (RBD), with two replicates, each block consisting of 12 plots randomly distributed, each corresponding to one treatments. The following characteristics were evaluated: coffee leaf rust intensity and severity, cercosporiosis and coffee leaf miner, plants vegetative vigor, grain maturity uniformity and plants height. The progeny averages were grouped by the Scott \& Knott test at 5\% probability. Progenies 27, 30 and 15 were selected, since they presented low incidence in relation to coffee leaf rust, cercosporiosis and coffee leaf miner, and will be used to continue the breeding program.
\end{abstract}

Index terms: Coffea arabica, genetic breeding, diseases.

\section{INCIDÊNCIA E SEVERIDADE DE FERRUGEM, CERCOSPORIOSE E BICHO MINEIRO EM PROGÊNIES DE CAFÉ}

RESUMO: A ferrugem do cafeeiro é a principal doença da cultura, contudo a cercosporiose e bicho mineiro também podem causar danos significativos quando atingem altos níveis de infestação. O melhoramento genético de plantas visando a resistência é uma das melhores opções para o controle de doenças de plantas. Objetivou-se com este trabalho identificar progênies $\mathrm{F}_{3}$ de Coffea arabica portadoras de resistência durável à ferrugem, que apresentem menor incidência e severidade de cercosporiose e bicho mineiro. Os tratamentos foram constituídos por 10 progênies, além de duas cultivares suscetíveis à ferrugem, utilizadas como testemunha. Utilizou-se o delineamento em blocos casualizados (DBC), com duas repetições, cada bloco constituído por 12 parcelas distribuídas ao acaso, cada uma destas correspondendo a um tratamento. Foram avaliadas as seguintes características: incidência e severidade de ferrugem, cercosporiose e bicho mineiro, vigor vegetativo das plantas, uniformidade de maturação dos grãos e altura das plantas. As médias das progênies foram agrupadas pelo teste de Scott \& Knott a $5 \%$ de probabilidade. As progênies 27, 30 e 15 foram selecionadas por apresentar baixa incidência em relação à ferrugem, cercosporiose e ao bicho mineiro, e serão utilizadas para dar continuidade ao programa de melhoramento.

Termos para indexação: Coffea arabica, melhoramento genético, doenças.

\section{INTRODUCTION}

Coffee is one of the most consumed beverages in the world. Brazil is the largest producer and exporter and the second largest consumer, generating an important source of wealth for the country. It is one of the main crops of Brazilian agribusiness, mainly in the state of Minas Gerais, where the South of Minas Gerais stands out in the activity (CONAB, 2018).

During crop management farmers may face several problems, including phytosanitary problems. In this context, we can highlight the coffee leaf rust caused by the fungus Hemileia vastatrix Berkeley \& Broome, which is the main disease of the crop, and can cause serious financial damage to coffee growers (REZENDE et al., 2013; TALHINHAS et al., 2016; ZAMBOLIM, 2016). Other diseases and pests can cause significant damage, such as cercosporiosis, caused by the fungus Cercospora coffeicola Berkeley \& Cooke (POZZA; CARVALHO; CHALFOUN, 2010) and the known as coffee leaf miner (Leucoptera coffeella Guérin-Mèneville \& Perrottet) (MAGALHAES et al., 2010).

\footnotetext{
1,2,3,4,5 Universidade Federal de Lavras/UFLA - Departamento de Agricultura/DAG - Cx. P. 3037 - $37.200-000$ - Lavras - MGeduardolima@prp.ufla.br,hudinilson@hotmail.com, elisa.castro@prp.ufla.br, samuelpc@dag.ufla.br, fabiano.francads@gmail.com 'Instituto Agronômico de Campinas - Centro Pesquisa de Ação Regional "Unidade de Pesquisa e Desenvolvimento de Mococa"Cx. P. 58 - 13.730-970 - Mococa - SP - slimajr@iac.sp.gov.br ${ }^{7}$ Universidade Estadual Paulista, Júlio de Mesquita Filho/UNESP- Campus de Registro - SP - 11.900-000 - Registro - SP alexcarvalho@registro.unesp.br
}

Coffee Science, Lavras, v. 13, n. 3, p. 349 - 355, jul./sep. 2018 
Cercosporiosis is found in the majority of coffee growing regions of Brazil, causing injuries in the leaves and fruits (SANTOS et al., 2008; PEREIRA et al., 2011). The disease symptoms in leaves are circular in format, with a dark brown colored spot encircled by a light yellow halo. This fungi presence stimulates the plant to produces ethylene which can cause intense defoliation, creating quantitative losses, reducing the yield and productivity of the culture, even in reduced severity (CUSTÓDIO et al., 2011). According to Botelho et al. (2017), there is genetic variability to $C$. coffeicola resistance among the coffee tree in different genotypes and genetic improvements could be obtained by selection.

The coffee leaf miner is an exotic African pest and it is considered monophagous. High attack levels reduce the photosynthetic capacity due to the leaf area reduce and their occurrence is strongly tied to meteorological factors (ZAMPIROLI et al., 2017). It may cause up to $70 \%$ defoliation (SCALON; MATEUS; ZACARIAS, 2013).

Brazilian Arabic coffee production is based on a set of highly productive cultivars susceptible to coffee leaf miner, and most of them are also susceptible to coffee leaf rust (MENDONÇA et al., 2016). Among the control methods for coffee leaf rust, chemical control is the most used. Although it is efficient if carried out indiscriminately and incorrectly it can bring diverse environmental and phytosanitary problems, besides the high cost and probability of resistance of phytopathogens (ZAMBOLIM et al., 2005). In this context, the use of varieties that are resistant or tolerant to pests and diseases is presented as a more economical, viable and sustainable alternative (BOISSEAU et al., 2009; CARVALHO et al., 2017; CARVALHO et al., 2012).

The use of cultivars without coffee leaf rust tolerance is widespread in the production systems and may differ in the degree of susceptibility, since resistant cultivars may become susceptible over time to new breeds of fungus originated by genetic mutations (FAZUOLI et al., 2007). This fungus has a very large genome (about $797 \mathrm{Mbp}$ ) and hides great pathological diversity. Currently, more than 50 physiological races of coffee leaf rust have been identified by the CIFC (Center for the Research of Coffee Rust) (TALHINHAS et al., 2017). In the improvement of the coffee tree, the cultivars with durable resistance are mainly obtained.
In breeding programs, it is desirable that new cultivars under development should be superior to their predecessors, which have, besides pest and disease resistance, improvements of other agronomic characteristics (MATIELLO et al., 2008; RAMALHO et al., 2012), aiming to reconcile cultivars with high yield, resistance to coffee leaf rust and less incidence of cercosporiosis (CARVALHO et al., 2017). The objective in this study was to identify Coffea arabica $\mathrm{L}_{\text {. }} \mathrm{F}_{3}$ progenies with durable resistance to coffee leaf rust, with lower incidence and severity of cercosporiosis and coffee leaf miner, and to evaluate the height, maturity uniformity and vegetative vigor.

\section{MATERIAL AND METHODS}

Progenies of coffee trees (C. arabica .) at two and a half years were evaluated in $\mathrm{F}_{3}$ generation. The methodology used to obtain these progenies was adaptation of recurrent selection model to the coffee tree. The initial population was obtained by means of artificial hybridization carried out in 2009, involving five groups: Catuaí ( LCH2077-2-5-02, LCH-2077-2-5-10, LCH-2077-2517, LCH-2077-2-5-62, LCH-2077-2-5-99), Icatu (MG-3282, MG-4040, MG-4042, MG-2942, MG2944, MG-4040-179, MG-4042-222), Topázio (MG-5002), Rubi (MG-1192) and Acaiá (LCP474-19). The cultivars were crossed according to a diallel scheme, in which each parental was crossed twice. The cultivar Acaiá LCP-474-19 was crossed in another diallel with Catuaí (LCH-2077-2-5-17, LCH-2077-2-5-62, LCH-2077-2-5-99) and Rubi MG -1192. 40 progenies were obtained, and the control cultivars were added for the selection of families within each selected progeny (Catuaí vermelho LHC-2077-2-5-15, LHC-2077-2-5-44, LHC-2077-2 LCP-379-19, LCP-388-17, Acaiá LPC-474-19, Icatu MG-3282, MG-2942, MG2944 and Rubi MG-1192). The $\mathrm{F}_{\text {s }}$ seeds obtained from this hybridization were used for production of seedlings. Of these 40 progenies, there was an advance of one generation, and from this new generation the 10 best progenies were selected. The control cultivars (Mundo Novo and Topázio), susceptible to coffee leaf rust, were added to the selection of families within each selected progeny (Table 1). The selected $F_{3}$ seeds were used to produce seedlings, following the usual production system of the region.

The trial was carried out in Lavras, MG, at the campus of the Federal University of Lavras (UFLA), in the Department of Agriculture, latitude south $21^{\circ} 14^{\prime} 06^{\prime \prime}$, longitude west $44^{\circ} 59^{\prime} 00^{\prime \prime}$ and altitude of approximately $910 \mathrm{~m}$. 
TABLE 1 - Coffea arabica L. $_{3}$ progenies implanted in experiment in Lavras, MG

\begin{tabular}{cc}
\hline Progenies $\mathrm{F}_{3}$ & Genealogy \\
\hline 4 & 119 (Icatu $4042 \times$ Catuaí 99) \\
12 & 117 (Icatu 2944 x Catuaí 17) \\
15 & 101 (Catuaí 10 x Icatu 4040) \\
26 & 127 (Icatu $3282 \times$ Catuaí 99) \\
27 & 141 (Icatu 2944 x Catuaí 62) \\
30 & 108 (Catuaí 02 x Icatu 4042) \\
31 & 142 (Icatu 2942 x Catuaí 62) \\
35 & 128 (Icatu 3282 x Catuaí 62) \\
39 & Acauã normal 1365 \\
41 & 116 (Icatu 2944 x Rubi) \\
MN & Mundo Novo \\
$\mathrm{T}$ & Topázio \\
\hline
\end{tabular}

The climate of region according to Koppen is humid temperate with hot summer and dry winter (OMETTO, 1981), the annual average temperature is $19.4^{\circ} \mathrm{C}$, the annual average total rainfall is $1,590 \mathrm{~mm}$ and the average annual relative humidity is $76 \%$. The soil of the experimental area is classified as red-dystroferric oxisol.

In 2012, $\mathrm{F}_{3}$ seeds were collected from this material. In March 2013, seedlings were formed and in December of this year the seedlings were planted in the $3.0 \mathrm{~m} \times 0.8 \mathrm{~m}$ spacing on the UFLA campus.

The experimental design was in randomized blocks, with two replicates, each block consisting of 12 randomly distributed plots, each corresponding to a different progeny. Each experimental plot contains 10 plants.

The vegetative vigor was evaluated through notes using an arbitrary scale of 10 points, where note 1 refers to the worst plants, with very low and marked vigor, which characterizes depletion and note 10 to plants with excellent vigor, more leafy and with marked vegetative growth of productive branches (SHIGUEOKA et al., 2014).

For the maturation uniformity, an arbitrary scale of 100 points was used, where note 1 refers to the plants with less maturity uniformity, and note 100 to plants with excellent maturity uniformity.

The height in centimeter of the plants was measured using a ruler, from the base of stem to the top of canopy.

Each of plants was evaluated as follows: leaves of the middle third of the plants were sampled, being five leaves of each side, always having as reference the third or fourth pair of leaves.

The incidence and severity of infestation of coffee leaf rust ( $H$. vastatrix), cercosporiosis (C. coffeicola) and coffee leaf miner (L. coffeella) were evaluated. For coffee leaf rust, the incidence was estimated by counting the number of leaves with sporulated pustules, and dividing by the total number of leaves of the sample, and multiplying the value found by 100 . For severity, the incidence was estimated by the number of pustules per leaf, dividing this value by the number of infected leaves, being expressed in average of pustules per infected leaf (CARDOSO et al., 2016; RIBEIRO; BERGAMIM FILHO; CARVALHO, 1981). The same methodology was used for cercosporiosis and coffee leaf miner.

The collection and evaluation were carried out in June 2016, three weeks before harvest. Throughout the harvest, the cultural treatments were made according to the recommendations for the crop, without the chemical control of coffee leaf rust, cercosporiosis and coffee leaf miner.

Data were submitted to analysis of variance (Test F) and the means of the progenies were grouped by the Scott \& Knott test at 5\% probability.

\section{RESULTS AND DISCUSSION}

For the Vegetative Vigor (VV), it can be observed that there was no significant difference between the progenies (Table 2), which presented the same note as the controls, recognized by the high vigor (ANDRADE et al., 2013; SILVA et al. 2016). 
TABLE 2 - Average vegetative vigor, height, maturation uniformity, severity and incidence of coffee leaf rust, cercosporiosis and coffee leaf miner.

\begin{tabular}{cccccccccc}
\hline Progenies & VV & HEIGHT & MU & RS & RI & CS & CI & LMS & LMI \\
\hline 4 & $8.20 \mathrm{a}$ & $126.50 \mathrm{a}$ & $77.145 \mathrm{~b}$ & $2.95 \mathrm{a}$ & $31.90 \mathrm{~b}$ & $1.15 \mathrm{~b}$ & $9.30 \mathrm{a}$ & $0.50 \mathrm{a}$ & $0.70 \mathrm{a}$ \\
12 & $8.45 \mathrm{a}$ & $145.00 \mathrm{a}$ & $87.000 \mathrm{a}$ & $5.00 \mathrm{~b}$ & $21.60 \mathrm{~b}$ & $1.05 \mathrm{~b}$ & $5.65 \mathrm{a}$ & $0.50 \mathrm{a}$ & $6.45 \mathrm{c}$ \\
15 & $8.65 \mathrm{a}$ & $149.00 \mathrm{a}$ & $87.915 \mathrm{a}$ & $3.80 \mathrm{a}$ & $8.70 \mathrm{a}$ & $1.10 \mathrm{~b}$ & $15.00 \mathrm{~b}$ & $1.00 \mathrm{~b}$ & $3.35 \mathrm{~b}$ \\
26 & $8.65 \mathrm{a}$ & $138.50 \mathrm{a}$ & $86.500 \mathrm{a}$ & $1.30 \mathrm{a}$ & $20.00 \mathrm{~b}$ & $1.40 \mathrm{c}$ & $16.35 \mathrm{~b}$ & $0.50 \mathrm{a}$ & $1.65 \mathrm{a}$ \\
27 & $8.95 \mathrm{a}$ & $130.00 \mathrm{a}$ & $87.125 \mathrm{a}$ & $1.65 \mathrm{a}$ & $5.00 \mathrm{a}$ & $1.00 \mathrm{~b}$ & $3.25 \mathrm{a}$ & $0.50 \mathrm{a}$ & $1.00 \mathrm{a}$ \\
30 & $9.05 \mathrm{a}$ & $135.50 \mathrm{a}$ & $88.615 \mathrm{a}$ & $2.40 \mathrm{a}$ & $5.55 \mathrm{a}$ & $0.65 \mathrm{a}$ & $3.90 \mathrm{a}$ & $1.00 \mathrm{~b}$ & $0.55 \mathrm{a}$ \\
31 & $8.55 \mathrm{a}$ & $107.50 \mathrm{a}$ & $89.645 \mathrm{a}$ & $3.60 \mathrm{a}$ & $29.00 \mathrm{~b}$ & $0.50 \mathrm{a}$ & $2.15 \mathrm{a}$ & $0.50 \mathrm{a}$ & $2.15 \mathrm{a}$ \\
35 & $8.50 \mathrm{a}$ & $131.00 \mathrm{a}$ & $87.500 \mathrm{a}$ & $5.30 \mathrm{~b}$ & $23.35 \mathrm{~b}$ & $1.35 \mathrm{c}$ & $15.00 \mathrm{~b}$ & $0.50 \mathrm{a}$ & $0.65 \mathrm{a}$ \\
39 & $8.10 \mathrm{a}$ & $119.00 \mathrm{a}$ & $79.835 \mathrm{~b}$ & $5.00 \mathrm{~b}$ & $6.85 \mathrm{a}$ & $1.65 \mathrm{c}$ & $5.50 \mathrm{a}$ & $1.25 \mathrm{~b}$ & $1.65 \mathrm{a}$ \\
41 & $8.65 \mathrm{a}$ & $141.50 \mathrm{a}$ & $87.680 \mathrm{a}$ & $6.15 \mathrm{~b}$ & $26.20 \mathrm{~b}$ & $1.15 \mathrm{~b}$ & $6.45 \mathrm{a}$ & $1.00 \mathrm{~b}$ & $3.80 \mathrm{~b}$ \\
MN & $7.35 \mathrm{a}$ & $168.00 \mathrm{a}$ & $84.165 \mathrm{a}$ & $8.85 \mathrm{c}$ & $64.80 \mathrm{~d}$ & $1.10 \mathrm{~b}$ & $4.10 \mathrm{a}$ & $2.55 \mathrm{c}$ & $7.45 \mathrm{c}$ \\
$\mathrm{T}$ & $8.45 \mathrm{a}$ & $131.50 \mathrm{a}$ & $86.135 \mathrm{a}$ & $6.80 \mathrm{~b}$ & $43.00 \mathrm{c}$ & $0.70 \mathrm{a}$ & $2.50 \mathrm{a}$ & $1.10 \mathrm{~b}$ & $6.50 \mathrm{c}$ \\
\hline
\end{tabular}

Averages followed by the same letter in the same column belong to the same group by the Scott \& Knott test at 5\% probability. Caption: VV = Vegetative vigor; $\mathrm{MU}=$ Maturation uniformity; RS. = Rust severity; RI = Rust incidence; $\mathrm{CS}=$ Cercosporiosis severity; $\mathrm{CI}=$ Cercosporiosis incidence; $\mathrm{LMS}=$ Leaf miner severity; LMI. $=$ Leaf miner incidence.

Coffee plants with high VV present lesser impoverishment, higher yield and consequently greater tolerance to pests and diseases. The VV is related to the adaptation capacity of the cultivars in the different edaphoclimatic conditions in which they are grown (CARVALHO et al., 2017). All the progenies presented a good performance in relation to the $\mathrm{VV}$, characterizing a good adaptability to the environment.

Plant height is a very important feature in the recommendation of cultivars, as this is directly related to the ease of handling of the crop and harvesting operations. For this characteristic, it is observed that although there is variation among progeny averages, there was no significant difference (Table 2). This fact may be related to the variation between the plants within the progenies. In the genetic improvement of the coffee tree, plants in the $\mathrm{F}_{3}$ generation show segregation, which may have contributed to the fact that the progenies still do not present uniformity and there is significant difference between the means of the progenies.

For maturation uniformity, two distinct groups were formed statistically, and the lowest averages observed were of progenies 4 and 39 .
Among the other progenies there was no significant difference. Fruit uniformity is an important and desirable feature, since coffee beans harvested at the cherry maturation stage present better beverage quality (LEROY et al., 2006).

It was possible to identify a significant difference in the incidence and severity of coffee leaf rust, cercosporiosis, and coffee leaf miner. According to Ivoglo et al., 2008, this fact may indicate the presence of genetic variability among the progenies.

Regarding the leaf rust severity (RS), the formation of three distinct groups was statistically significant, where the lowest averages were of the progenies $26,27,30,4,31$ and 15 , and the highest RS was observed in cultivar Mundo Novo, who is one of the witnesses and is highly susceptible. The cultivar Acauã (progeny 39), recognized for resistance to this pathogen (CARVALHO et al., 2012; GROSSI et al., 2013), was in the intermediate group for severity, evidencing the potential of the hybrids under study.

Progenies 27, 30, 39 and 15 presented lower leaf rust incidence and cultivars Mundo Novo and Topázio presented higher RI. Most progenies are derived from Icatu, which originates from the artificial cross of Coffea canephora Pierre with the cultivar Bourbon Vermelho of C. arabica. 
The cultivar Icatu presents rusticity, high vegetative vigor, good yield and variability for resistance to coffee leaf rust, both specific and non-specific (SERA et al., 2010).

The progenies 27, 30 and 15 that obtained good results for RI and RS were highlighted. In the case of coffee leaf rust resistance of the nonspecific or polygenic type, it is desirable because it is durable, while the specific resistance can be broken by new genotypes of the pathogen (COSTA et al., 2013). Most of the hybrids studied presented low RI and RS, a fact that is desired by researchers because they are sources of durable and efficient resistance against multiple races of a specific pathogen (REZENDE et al., 2017), not hiding the expression of horizontal resistance (BOTELHO et al. al., 2010).

According to Carvalho et al. (2017), cercosporiosis is a disease that has increased its incidence in coffee crops in recent years and has gained great importance due to the economic damage caused in the crop. Regarding the severity and incidence of this disease, progenies 31,30 and Topázio worse mean values, while progenies 26 and 35 remained in the group with the highest values for the disease showing less promising.

Three different groups were statistically significant for leaf miner severity. The best means were from progenies $27,26,35,31,4$ and 12 , being the highest severity observed in the cultivar Mundo Novo. Regarding to leaf miner incidence, the best averages were those of $30,35,4,27,39$, 26 and 31, and the worse averages were found in Mundo Novo, Topázio and 12.

Some progenies stood out with good averages in several evaluated characters, and this was observed to rank the best ones. Progenies 30, 27 and 15 obtained the best means in relation to RI and RS. At 30 and 27, they presented the best means in six of the seven characters evaluated, where progeny 30 was classified in the second best mean group in relation to LMS and progeny 27 in the second best mean group in relation to CS. And the progeny 15 obtained a relatively good performance in the other characters, being present in the second group of better means of these characters.

\section{CONCLUSIONS}

Variability was observed among progenies considering the vegetative vigor and the susceptibility of progenies to coffee leaf rust, cercosporiosis and coffee leaf miner.
Progenies 27, 30 and 15 have been indicated to be more tolerant to coffee leaf rust, cercosporiosis and coffee leaf miner, and may be used to continue the breeding program.

\section{ACKNOWLEDGMENTS}

The authors acknowledge to FAPEMIG (Foundation for Supporting Research of the State of Minas Gerais), CNPq (National Council for Scientific and Technological Development) and CAPES (Coordination for the Improvement of Higher Education Personnel) for financial support during this study.

\section{REFERENCES}

ANDRADE, V. T. et al. Interação genótipo $\mathrm{x}$ ambiente em genótipos de cafeeiro Mundo Novo por modelos não lineares e multiplicativos. Bragantia, Campinas, v. 72, n. 4, p. 338-345, Oct/Dec. 2013.

BOISSEAU, M. et al. Resistance to Meloidogyne paranaensis in wild Coffea arabica. Tropical Plant Pathology, Brasília, v. 34, n. 1, p. 38-41, Jan/Feb. 2009.

BOTELHO, C. E. et al. Seleção de progênies F4 de cafeeiro obtidas pelo cruzamento de Icatu com Catimor. Revista Ceres, Viçosa, MG, v. 57, n. 3, p. 274-281, May/June. 2010.

BOTELHO, D. M. S. et al. Cercosporiosis resistance in coffee germplasm collection. Euphytica, v. 213, n. 6, p. 117, June, 2017.

CARDOSO, D. A. et al. Seleção de progênies f4 de cafeeiros com resistência à ferrugem na região sul de minas gerais. Coffee Science, Lavras, v. 11, n. 4, p. 555-566, Oct/Dec. 2016.

CARVALHO, A. M. et al. Desempenho agronômico de cultivares comerciais de café resistentes à ferrugem no Estado de Minas Gerais. Bragantia, Campinas, v. 71, n. 4, p. 481- 487, Oct/Dec. 2012.

CARVALHO, A. M. et al. Comportamento de cultivares de cafeeiro sob a incidência das doenças da ferrugem e cercosporiose em dois ambientes de cultivo. Coffee Science, Lavras, v. 12, n. 1, p. 100-107, Jan/Mar. 2017.

COMPANHIA NACIONAL DE ABASTECIMENTO (CONAB). Acompanhamento da safra brasileira de café, safra 2018, primeiro levantamento. 2018. Available on: <http://www.conab.gov.br/>. Access in: 28 jan. 2018. 
COSTA, J. C. et al. Field performance of coffee progenies and cultivars with specific resistance to rust. Coffee Science, Lavras, v. 8, n. 2, p. 183-191, Apr/ June. 2013.

CUSTÓDIO, A. A. P. et al. Comparação e validação de escalas diagramáticas para cercosporiose em folhas de cafeeiro. Ciência e Agrotecnologia, Lavras, v. 35, n. 6, p. 1067-1076, Nov/Dez. 2011.

FAZUOLI, L. C. et al. A ferrugem alaranjada do cafeeiro e a obtenção de cultivares resistentes. O Agronômico, Campinas, v. 59, n. 1, p. 48-53. 2007.

GROSSI, L. et al. Rust resistance in arabic coffee cultivars in northern Paraná. Brazilian Archives of Biologyand Technology, Curitiba, v. 56, n. 1, p. 27-33, Jan/Feb. 2013.

IVOGLO, M. G. et al. Divergência genética entre progênies de café robusta. Bragantia, Campinas, v. 67, n. 4, p. 823-831, Oct/Dec. 2008.

LEROY, T. et al. Genetics of coffee quality. Brazilian Journal or Plant physiology, Londrina, v. 18, n. 1, p. 229-242, Jan/Mar. 2006.

MAGALHÃES, S.T. et al. Leaf Alkaloids, Phenolics, and Coffee Resistance to the Leaf Miner Leucoptera coffeella (Lepidoptera: Lyonetiidae). Journal of Economic Entomology, Annapolis, v. 103, n. 4, p. 1438-1443, July/Aug. 2010.

MATIELLO, J. B. Critérios para a escolha de cultivar de café. In: CARVALHO, C. H. S. de (Ed.). Cultivares de café: origem, características e recomendações. Brasília: EMBRAPA Café, 2008. v. 1, p. 157-226.

MENDONÇA, A. P. N. et al. Coffea arabica clones resistant to coffee leaf miner. Crop Breeding and Applied Biotechnology, Viçosa, v. 16, n. 1, p. 42-47, Jan/Mar. 2016.

OMETTO, J. C. Bioclimatologia Vegetal. São Paulo: Ceres, 1981. 425p.

PEREIRA, R. B. et al. Potential of essential oils for the control of brown eye spot in coffee plants. Ciência e Agrotecnologia, Lavras, v. 35, n. 1, p. 115-123, Jan/ Feb. 2011.

POZZA, E. A; CARVALHO, L. C; CHALFOUN, S. M. Sintomas de injúrias causadas por doenças em cafeeiro. In: GUIMAR ̃̂ES, R.J; MENDES A.N.G; BALIZA
D.P. (eds). Semiologia do cafeeiro: Sintomas de desordens nutricionais, fitossanitárias e fisiológicas. Lavras: Editora UFLA, 2010. p. 68-106.

RAMALHO, M. A. P. et al. Aplicações da genética quantitativa no melhoramento de plantas autógamas. Lavras: Editora UFLA, 2012. 522 p.

REZENDE, R. M. et al. Resistance of Coffea arabica progenies in field conditions infested by Meloidogyne exigua. Nematropica, Bradenton, v. 43, n. 2, p. 233240, July/Dec. 2013.

REZENDE, R. M. et al. Agronomic characterization and responses to coffee leaf rust in coffee progenies resistant to the gall nematode Meloidogyne exigua. Semina: Ciências Agrárias, Londrina, v. 38, n. 2, p. 671-682, Mar/Apr. 2017.

RIBEIRO, I. J. A.; BERGAMIM FILHO, A.; CARVALHO, P. C. T. Avaliação da resistência horizontal a Hemileia vastatrix Berket Br. em cultivares de Coffea arabica L. em condições naturais de epidemia. Summa Phytopathologica, Piracicaba, v. 7, n. 1-2, p. 80-95, Apr/June. 1981.

SANTOS, F. da S. et al. Progress of brown eye spot (Cercospora coffeicola Berkeley and Cooke) in coffee trees in organic and conventional systems. Summa Phytopathologica, Botucatu, v. 34, n. 1, p. 48-54, Jan/ Feb. 2008.

SCALON, J. D.; MATEUS, A. L. S. S.; ZACARIAS, M. S. Análise espaço-temporal do nível de infestação do bicho-mineiro Leucoptera coffeella, (Guérin-Menèville \& Perrottet, 1842) (Lepidoptera: Lyonetiidae) em cafezal orgânico (Coffea arabica L.). Coffee Science, Lavras,v. 8, n. 3, p. 347-353, Jul/Set. 2013.

SERA, G. H. et al. Resistência à ferrugem alaranjada em cultivares de café. Coffee Science, Lavras, v. 5, n. 1, p. 59-66, Jan/Apr. 2010.

SHIGUEOKA, L. H. et al. Selection of Arabic coffee progenies with rust resistance. Crop Breeding and Applied Biotechnology, Viçosa, v. 14, n. 2, p. 88-93, Apr/June. 2014.

SILVA, V. A. et al. Recuperação de cultivares de café submetidas ao esqueletamento aos quatro anos e meio de idade. Coffee Science, Lavras, v. 11, n. 1, p. 55-64, Jan/Mar. 2016. 
TALHINHAS, P. et al. The coffee leaf rust pathogen Hemileia vastatrix: one and a half centuries around the tropics. Molecular Plant Pathology, v. 18, n. 8, p. 1039-1051, Oct/Nov. 2016.

ZAMBOLIM, L. Current status and management of coffee leaf rust in Brazil. Tropical Plant Pathology, Brasília, v. 41, n. 1, p. 1-8, Feb. 2016.

ZAMBOLIM, L.; VALE, F.X.R.; ZAMBOLIM, E.M. Doenças do cafeeiro (Coffea arabica e Coffea canephora). In: KIMATI, H.; AMORIM,
L.; REZENDE, J.A.M.; BERGAMIM FILHO, A.; CAMARGO, L.E.A. (Ed.). Manual de fitopatologia: doenças das plantas cultivadas. 4.ed. São Paulo: Agronômica Ceres, 2005. 663p.

ZAMPIROLI, R. et al. Application technology for chemically controlling coffee leaf miner in the cerrado of Minas Gerais State. Revista de Ciências Agrárias/Amazonian Journal of Agricultural and Environmental Sciences, Belém, v. 60, n. 3, p. 256262, July/Sept. 2017. 